\title{
特集に寄せて
}

\author{
信頼性解析技術委員会委員長 涉谷 忠弘 *
}

\section{Intention to the Special Edition}

Tadahiro SHIBUTANI*

*横浜国立大学大学院環境情報研究院（† 240-8501＼cjkstart神奈川県横浜市保土ヶ谷区常盤台 79-5）

*Faculty of Environment and Information Science, Yokohama National University (79-5 Tokiwadai, Hodogaya-ku, Yokohama-shi, Kanagawa 240-8501)

宇宙科学研究所(ISAS) が打ち上げた小惑星探査機「はや ぶさ」が，60億 $\mathrm{km}$ の旅を終え地球に帰還した。幾多のト ラブルを乗り越え帰還したその姿は, 多くの人に感動を与 えた。

「はやぶさ」も，数多くのエレクトロニクス実装製品を 内包する電子情報システムの 1 つであり, 実装信頼性はシ ステムを脅かす要因の 1 つである。当時の技術の粋を集め たシステムの満身創痍の姿は, エレクトロニクス実装にお ける信頼性解析技術のより一層の向上を示唆しているとも いえなくもない。

多くのエレクトロニクス製品において, 高集積化・高密 度化が進んでおり，システムのさらされる環境も厳しく なっている。このため, 高集積化・高密度化したエレクト ロニクスで構成される電子情報システムの信頼性の確保は 容易ではない。また，近年はスマートグリッドをはじめと するエネルギエレクトロニクスにおける実装信頼性問題も 顕在化している。このような電子情報システムにおける信 頼性問題に対しては, 従来のように個々の電子部品の信頼 性がシステムの信頼性に寄与するだけでなく, 複雑な相互 作用因子が故障の主要因となること屯少なくない。また， 複数の故障が連鎖的に発生するような複雑な故障モードも 多い。このような信頼性の問題に対して, 従来の故障解析 や信頼性評価技術では対応しきれなくなってきている現状 がある。

複雑な電子情報システムの信頼性問題の解決策の 1 つ して, 欧米を中心に未然防止型の信頼性評価手法として Prognostics（故障予知）が注目されつつある。フィールド 環境や損傷を適切にモニタリングして，高精度な余寿命評 価を行い最適な維持管理計画を構築することで効率のよい 電子情報システムの管理が可能となる。また，近年の情報
技術の格段の進歩に伴い，フィールド環境での膨大なデー 夕のモニタリングも一部可能になりつつある。このような, 健全性評価技術（ヘルスモニタリング）は一部の産業分野 （電力や船舶など）ではすでに採用されている。上述の工 ネルギエレクトロニクスについても，故障した場合の社会 的影響が大きく, 故障予知技術の需要は大きい。しかし, 電子情報システムへの実装は非常に困難な問題を抱えてい る。例えば，センサの取り付け 1 つをとっても，高密度実 装では設計空間が限られており非常に困難な問題となる。

信頼性解析技術委員会では，エレクトロニクス実装技術 にかかわる信頼性問題および技術動向について調査・議論 を進めている。これまで，エレクトロニクス実装について 主要な信頼性問題についていち早く研究会などを立ち上げ, 海外の動向について情報収集を行うとともに会員への普及 活動につとめてきた。

今回，信頼性解析技術委員会として「故障を予測するた めの信頼性技術の最前線」と題し特集を企画させていただ いた。エレクトロニクス実装製品における Prognostic and Health Management（故障予知によるシステム健全性管理 技術：PHM）の第一人者であるメリーランド大学の Michael Pecht 教授にPHMの最新の状況を紹介していただ くとともに，故障予測に深くかかわるシステムモニタリン グ，熱設計，シミュレーション技術，加速試験および絶縁 信頼性試験の動向について最前線の研究者による解説をお 願いした。また，新材料や新分野への適用可能性として次 世代 $\mathrm{SiC}$ パワーモジュールにおける実装技術の課題につい てもとりあげている。「故障予測技術」は，信頼性解析技 術の中でも最も困難な技術の 1 つであり，幅広い技術が融 合した総合技術でもある。特集した内容は多岐にわたって いるが，会員諸氏に有益な知見が提供できれば幸いです。 